\title{
UM MUNDO ALÉM DO HUMANO ${ }^{1}$
}

\section{DAVID ABRAM ${ }^{2}$}

STATE UNIVERSITY OF NEW YORK

RESUMO: A partir de um projeto inicial que visava investigar a relação entre a mágica e a medicina tradicional conforme praticada pelos xamãs tradicionais das regiões rurais do sul da Ásia, o enfoque passou gradativamente para uma atenção à negociação que as pessoas da medicina ou xamãs estabelecem entre a comunidade humana e a comunidade mais ampla de seres. Essa atenção ao mundo além do humano não ocorre em um domínio supernatural acima da natureza ou dentro da psiquê pessoal do xamã, porém é o resultado da habilidade especial do xamã de projetar sua consciência horizontalmente em direção a outras formas de sensibilidade com as quais a existência humana está entrelaçada. A função ecológica do xamã consiste em manter um equilíbrio constante entre o que é retirado e o que é dado de volta para a comunidade mais ampla. Os espíritos das culturas indígenas não são definidos em oposição à materialidade, mas são essencialmente aqueles modos de inteligência ou atenção que não possuem forma humana. Ao explorar paisagens diferentes e as inteligências que nelas vivem, uma nova sensibilidade despertou, permitindo a comunicação com aquelas inteligências. Entretanto, o abafamento dessas outras vozes na cultura ocidental, que reduz o outro a um objeto, produz um mal-estar que dificilmente é percebido a não ser como uma incapacidade de interagir com tudo além do humano e suas consequências na forma do comportamento destrutivo da "civilização".

PALAVRAS-CHAVE: Mágica; percepção; shamanismo; culto aos ancestrais; animismo; natureza.

ABSTRACT: From an initial project to investigate the relationship between magic and traditional medicine as practiced by shamans in Southern rural Asia, the focus of attention gradually shifted to an awareness of the negotiation traditional medicine people or shamans exert between the human

\footnotetext{
${ }^{1}$ Traduzido por Pietra Acunha Pereira a partir do original: ABRAM, David. The Spell of the Sensuous: Perception and Language in a More-Than-Human World. New York: Vintage, 1996. A alteração do nome do capítulo para esta publicação foi feita a pedido do autor. No entanto, chamamos a atenção para a existência de uma edição portuguesa do livro publicada em 2007 pela Fundação Calouste Gulbenkian e traduzida por João C. S. Duarte sob o título A magia do sensível: percepção e linguagem num mundo mais do que humano. $\mathrm{O}$ presente capítulo também foi traduzido, em junho de 2013, pela bióloga e analista ambiental Sandra Michelli da Costa Gomes com o título original. A tradução encontra-se no link http://transecoqueer.wordpress.com/2013/06/16/capitulo-1-a-ecologia-da-magica-uma-introducao-pessoal-ainvestigacao/ [Nota da tradutora].

${ }^{2}$ Ph.D. em filosofia pela State University of New York at Stony Book, ecologista e escritor freelance. E-mail: riverspell@earthlink.net.
}

Espaço Ameríndio, Porto Alegre, v. 7, n. 2, p. 64-95, jul./dez. 2013. 
DAVID ABRAM - Um mundo além do humano

community and the larger community of beings. This attentiveness to a more-than-human world does not occur at a supernatural domain above nature or inside her personal self but is the result of the shaman's special ability to project her consciousness horizontally to other forms of sensibility with which human existence is interwoven. The ecological function of the shaman is to maintain a constant balance between what is taken and what is given from the human community to the larger community. The spirits of indigenous cultures are not defined in opposition to materiality but are essentially those modes of intelligence or awareness that do not possess a human form. By exploring different landscapes, and the sensibility living in them, a new sensitivity is awoken that allows for communication with those intelligences. However, the drowning of these other voices in Western culture, which reduces otherness to an object, creates an uneasiness that is hardly perceived except as an inability to interact with anything more-than-human and its dire consequences in the form of "civilization's" destructive behavior.

KEYWORDS: Magic; perception; shamanism; ancestor worship; animism; nature.

Tarde da noite, saí de minha pequena cabana nos arrozais do leste de Bali e me vi caindo através do espaço. Acima da minha cabeça o céu negro ondulava com estrelas, agrupadas densamente em algumas regiões, quase bloqueando a escuridão entre elas e vagamente mais espalhadas em outras áreas, palpitando e acenando umas para as outras. Atrás de todas elas, o grande rio de luz corria serenamente com seus vários afluentes. No entanto, a Via Láctea agitava-se também abaixo de mim, já que minha cabana estava posicionada no meio de uma grande miscelânea de arrozais, separados uns dos outros por diques estreitos de sessenta centímetros de profundidade, e esses arrozais estavam todos cheios de água. A superfície dessas piscinas, durante o dia, refletia perfeitamente o céu azul, um reflexo quebrado somente pelo fino e brilhante verde dos brotos do arroz novo. Mas à noite as estrelas brilhavam da superfície dos arrozais, e o rio de luz rodopiava através da escuridão tanto sob meus pés quanto sobre minha cabeça; parecia não ter chão a minha frente, mas somente o abismo do espaço cheio de estrelas caindo eternamente.

Eu não estava simplesmente sob o céu noturno, mas também sobre ele - a primeira impressão era de leveza. Talvez tivesse sido capaz de me reorientar, para recuperar algum senso de solo e gravidade, se não fosse

Espaço Ameríndio, Porto Alegre, v. 7, n. 2, p. 64-95, jul./dez. 2013. 
DAVID ABRAM - Um mundo além do humano

por um fato que confundiu totalmente meus sentidos: entre as constelações abaixo e as constelações acima flutuavam incontáveis vagalumes, suas luzes piscando como as estrelas, alguns flutuavam subindo para juntarem-se aos aglomerados de estrelas acima, outros, como meteoros graciosos, deslizavam do alto para juntarem-se às constelações sob meus pés, e todos esses caminhos de luz para cima e para baixo estavam espelhados, também, na superfície imóvel dos arrozais. Em alguns momentos me sentia caindo através do espaço, em outros momentos flutuando e deslizando. Simplesmente não conseguia afastar a tontura e vertigem fortes; os caminhos dos vaga-lumes, e seus reflexos na superfície da água, mantiveram-me num transe contínuo. Mesmo depois de rastejar de volta para minha cabana e fechar a porta para esse mundo rodopiante, sentia que o pequeno quarto em que eu estava deitado naquele momento estava flutuando solto da terra.

Vaga-lumes! Veja bem, foi na Indonésia que fui apresentado pela primeira vez ao mundo dos insetos e foi lá que aprendi pela primeira vez sobre a grande influência que os insetos - entidades tão diminutas podem ter sobre os sentidos humanos. Viajei para Indonésia com uma bolsa de pesquisa para estudar mágica - mais precisamente para estudar a relação entre a mágica e a medicina, a princípio com os feiticeiros tradicionais, ou dukun, do arquipélago indonésio, e mais tarde com os dzankri, os xamãs tradicionais do Nepal. Um aspecto dessa bolsa era, de certa forma, ímpar: Eu iria fazer uma viagem para a Ásia rural, não no papel explícito de um antropólogo ou pesquisador acadêmico, mas como um mágico, na esperança de ter um acesso mais direto aos feiticeiros locais. Fui prestidigitador profissional por cinco anos nos Estados Unidos, fazendo apresentações em clubes e restaurantes por toda Nova Inglaterra, o que ajudou meu sustento na faculdade. Além disso, interrompi meus estudos em psicologia da percepção por um ano para viajar como mágico de rua pela Europa e, perto do fim de minha jornada, passei alguns meses em Londres, na Inglaterra, explorando o uso da prestidigitação em 
DAVID ABRAM - Um mundo além do humano

psicoterapia, como forma de melhorar a comunicação daqueles indivíduos conturbados que os terapeutas clínicos não estavam conseguindo tratar ${ }^{3}$.

$O$ sucesso desse trabalho me fez pensar que a prestidigitação podia ser usada nas artes curativas, e me interessei, pela primeira vez, pela relação, em grande parte esquecida no Ocidente, entre medicina tradicional e mágica.

Foi esse interesse que levou à bolsa de pesquisa citada anteriormente e a minha permanência temporária como mágico na Ásia rural. Lá, minhas habilidades em prestidigitação revelaram-se inestimáveis como uma forma de aguçar a curiosidade dos xamãs locais. Pois os mágicos - sejam os artistas modernos ou indígenas, feiticeiros tribais têm em comum o fato de trabalharem com a maleável textura da percepção. Quando os feiticeiros locais ficavam sabendo que eu tinha pelo menos alguma habilidade rudimentar em alterar o campo comum da percepção, me convidavam a suas casas, me pediam para ensinar alguns segredos e finalmente me encorajavam, e até mesmo insistiam, que participasse de vários rituais e cerimônias.

Mas o foco da minha pesquisa mudou gradativamente de questões relacionadas a aplicação de técnicas de mágica na medicina e nos rituais de cura em direção a uma ponderação mais profunda da relação entre a mágica tradicional e o mundo natural animado. Esse interesse mais amplo parecia ser a chave para as primeiras questões que surgiram. Pois nenhum dos vários feiticeiros da ilha que conheci na Indonésia, nem quaisquer dzankri com quem convivi no Nepal, consideravam seu trabalho de curandeiros ritualísticos como sendo seu papel ou função principal dentro de suas comunidades. A maioria deles, com certeza, eram os curandeiros principais ou os "médicos" dos vilarejos em sua vizinhança, e eles, muitas vezes, foram mencionados como tal pelos habitantes daqueles vilarejos. Mas os moradores às vezes também falavam deles, em voz baixa e em conversas muito privadas, como bruxos (ou “/ejak' em Bali), como mágicos negros que à noite poderiam muito bem estar praticando seus feitiços de

\footnotetext{
${ }^{3}$ Este trabalho foi realizado na associação Philadelphia Association, uma comunidade terapêutica dirigida pelo Dr. R. D. Laing e seus associados.
}

Espaço Ameríndio, Porto Alegre, v. 7, n. 2, p. 64-95, jul./dez. 2013. 
DAVID ABRAM - Um mundo além do humano

cura ao contrário (ou virando para a esquerda ao invés da direita) para afligir as pessoas com as mesmas doenças que mais tarde eles iriam curar durante o dia. Tais suspeitas pareciam bastante comuns na Indonésia e, frequentemente, eram nutridas em relação aos curandeiros mais efetivos e poderosos, aqueles que eram mais famosos por sua habilidade de expulsar doenças. Pois se presumia que, para poder expulsar as influências maléficas, um mágico deveria ter um grande conhecimento dessas influências e dos demônios - até mesmo, em algumas áreas, uma estreita relação com tais poderes. Pessoalmente nunca vi quaisquer desses mágicos ou xamãs que conheci utilizar a mágica para propósitos nocivos, nem nenhuma evidência convincente de que eles já o tivessem feito (Poucos mágicos que conheci aceitavam dinheiro em troca de seus serviços, embora eles aceitassem presentes na forma de comida, cobertores e coisas do gênero). No entanto, fiquei surpreso com o fato de que nenhum deles jamais fez ou disse algo para combater tais rumores e especulações inquietantes, que circulavam tranquilamente pelas regiões onde viviam. Aos poucos, fui percebendo que era através da ação de tais rumores, e dos medos ambíguos que tais rumores criavam nas pessoas do vilarejo, que os feiticeiros conseguiam manter um nível básico de privacidade. Se os moradores não alimentassem certos medos em relação ao feiticeiro local, então eles provavelmente viriam procurar ajuda mágica deles para qualquer doença pequena ou perturbação; e uma vez que um praticante mais poderoso deve prestar serviços para vários vilarejos grandes, o feiticeiro seria inundado da manhã à noite com pedidos de auxílio ritualístico. Ao permitir que inevitáveis suspeitas e medos circulassem desimpedidos na região (e às vezes até mesmo encorajando e contribuindo para tais rumores), o feiticeiro se assegurava que apenas aqueles que realmente precisassem de suas habilidades ousariam se aproximar para pedir ajuda.

Essa privacidade, por sua vez, deixava o mágico livre para se dedicar àquilo que ele reconhecia como seu ofício e função principais. Uma pista para esta função pode ser encontrada no fato de que tais mágicos raramente vivem no centro de seus vilarejos; ao contrário, suas habitações

Espaço Ameríndio, Porto Alegre, v. 7, n. 2, p. 64-95, jul./dez. 2013. 
DAVID ABRAM - Um mundo além do humano

normalmente se encontram num espaço periférico da comunidade ou, mais frequentemente, para além dos limites do vilarejo - entre os arrozais ou na floresta ou num aglomerado de rochas. O que poderia ser facilmente atribuído à recém-mencionada necessidade de privacidade, no entanto, para os mágicos numa cultura tradicional, parece servir também a outro propósito, dando uma expressão espacial a sua posição simbólica no que diz respeito à comunidade. Pois a inteligência do mágico não está limitada ao que acontece dentro da sociedade; seu lugar é na fronteira da comunidade mediando entre a comunidade humana e a comunidade mais ampla de seres, de quem o vilarejo depende para sua alimentação e sustento. Essa comunidade mais ampla inclui, juntamente com os humanos, as várias entidades não humanas que constituem a paisagem local, desde as diversas plantas e incontáveis animais - aves, mamíferos, peixes, répteis, insetos - que habitam ou migram pela região, até os padrões específicos de ventos e clima que influenciam a geografia local, como também os vários relevos - florestas, rios, cavernas, montanhas que dão seu caráter específico para a terra em redor.

O xamã tradicional ou tribal, conforme passei a perceber, age como um intermediário entre a comunidade humana e o campo ecológico mais amplo, garantindo que haja um fluxo apropriado de alimentação, não somente do meio ambiente para os habitantes humanos, mas também da comunidade humana de volta para a terra local. Através de seus rituais, transes, êxtases e "jornadas" constantes, ele assegura que a relação entre a sociedade humana e a sociedade mais ampla de seres esteja equilibrada e seja recíproca e que o vilarejo nunca retire mais da terra viva do que dá a ela - não apenas materialmente, mas também através de orações, propriciações e enaltecimento. A escala da colheita ou o tamanho da caça são sempre negociados entre a comunidade tribal e o mundo natural que ela habita. Em certa medida, todo adulto na comunidade está empenhado nesse processo de escutar e se sintonizar com outras presenças que o cercam e influenciam a rotina diária. Mas o xamã ou feiticeiro é um viajante exemplar no reino intermediário entre os mundos humano e além do

Espaço Ameríndio, Porto Alegre, v. 7, n. 2, p. 64-95, jul./dez. 2013. 
DAVID ABRAM - Um mundo além do humano

humano, o estrategista e negociador principal em quaisquer relações com os Outros.

E é apenas como resultado do seu contínuo engajamento com os poderes animados, que habitam além da comunidade humana, que o mágico tradicional é capaz de aliviar muitas doenças individuais que surgem dentro da comunidade. O feiticeiro busca sua habilidade de curar doenças de sua prática contínua de "curar" ou equilibrar a relação entre a comunidade e a terra ao seu redor. Em tais culturas, a doença é frequentemente conceitualizada como um tipo de desequilíbrio sistêmico dentro da pessoa doente ou, mais vividamente, como a intromissão de uma presença demoníaca ou malévola em seu corpo. Por vezes, há influências malévolas dentro do próprio vilarejo ou tribo que interferem na saúde e bem-estar emocional de indivíduos suscetíveis dentro da comunidade. No entanto, tais influências destrutivas dentro da comunidade humana são geralmente atribuídas a um desequilíbrio entre aquela comunidade e os amplos campos de forças em que está inserida. Apenas aquelas pessoas que, através de sua prática diária, estão envolvidas em monitorar e manter as relações entre o vilarejo humano e a paisagem são capazes de diagnosticar, tratar, e, por fim, aliviar adequadamente padecimentos pessoais e doenças que surgem dentro do vilarejo. Qualquer curandeiro que não estivesse cuidando da relação entrelaçada entre a comunidade humana e o campo mais amplo, além do humano, provavelmente afastaria uma doença de uma pessoa para, em seguida, ver o mesmo problema surgir (talvez sob nova forma) em outro lugar na comunidade. Por isso, o mágico ou a pessoa da medicina tradicional age primeiramente como um intermediário entre os mundos humano e não humano, e somente em segundo plano como um curandeiro ${ }^{4}$. Sem uma consciência continuamente ajustada do equilíbrio ou desequilíbrio relativo entre o grupo humano e seu

\footnotetext{
${ }^{4}$ Uma simples ilustração desse fato pode ser encontrada entre vários povos indígenas dos Estados Unidos, para quem o termo "medicina" normalmente traduz uma palavra que significa "poder" - em particular o poder sagrado que um ser humano recebe de um animal ou outra entidade não humana. Assim, uma determinada pessoa da medicina pode ser famosa por sua "medicina texugo", "medicina urso", pela sua "medicina águia", "medicina alce" ou, até mesmo, "medicina trovão". É pelo seu envolvimento direto com esses poderes não humanos que as pessoas da medicina obtêm suas próprias habilidades, incluindo sua habilidade de curar doenças.
}

Espaço Ameríndio, Porto Alegre, v. 7, n. 2, p. 64-95, jul./dez. 2013. 
DAVID ABRAM - Um mundo além do humano

ambiente não humano, junto com as habilidades necessárias para modular a relação primária, qualquer "curandeiro" é sem valor - de fato, não é, de modo algum, um curandeiro. Portanto, o grau mais alto de lealdade da pessoa da medicina não é dirigido à comunidade humana, mas à rede terrena de relações na qual aquela comunidade está inserida - é dessa relação que ela deriva seu poder de aliviar as doenças humanas - e isso distingue o mágico local das outras pessoas.

A primazia da natureza não humana para os mágicos - o cerne de sua relação com as outras espécies e com a terra - nem sempre é evidente para os pesquisadores Ocidentais. Incontáveis antropólogos negligenciaram a dimensão ecológica do ofício do xamã ao escrever extensivamente sobre a relação do xamã com as entidades "sobrenaturais". Podemos atribuir muito desse descuido ao pressuposto moderno e civilizado de que o mundo natural é fortemente determinado e mecânico e de que aquilo que é considerado misterioso, poderoso e além do alcance humano deve, portanto, pertencer a algum outro domínio não físico acima da natureza, "sobrenatural".

O descuido se torna ainda mais compreensível quando percebemos que muitos dos primeiros intérpretes europeus do modo de vida indígena eram missionários cristãos. Pois a Igreja há muito estabeleceu a ideia de que somente os seres humanos possuem almas inteligentes e que os outros animais, para não falar das árvores e dos rios, foram "criados" por nenhum outro motivo além de servir à humanidade. Podemos facilmente entender por que os missionários europeus, mergulhados no dogma do Cristianismo institucionalizado, pensaram se tratar de uma crença em poderes sobrenaturais além-mundo entre aquelas pessoas tribais que eles viam como elevados e em estado de transe induzidos por forças não humanas (mas ainda assim naturais). O que impressiona é o quanto a Antropologia contemporânea ainda mantém o viés etnocêntrico desses primeiros intérpretes. Não descrevemos mais os enigmáticos ajudantes espirituais dos xamãs como os "primitivos supersticiosos ignorantes" - nos purificamos, pelo menos, desse nível de etnocentrismo-; no entanto, ainda nos referimos a tais forças enigmáticas, agora de forma respeitosa, como

Espaço Ameríndio, Porto Alegre, v. 7, n. 2, p. 64-95, jul./dez. 2013. 
DAVID ABRAM - Um mundo além do humano

"sobrenaturais" - pois não somos capazes de nos desvencilhar da ideia, tão endêmica à civilização científica, da natureza como um domínio tão prosaico e previsível, inadequado a tais mistérios. Ainda assim, aquilo que é visto com grande admiração e deslumbramento pelas culturas orais indígenas é, sugiro, nada além daquilo que tomamos como sendo a própria natureza. Os poderes e as entidades profundamente misteriosas com que o xamã se relaciona são, no fim, as mesmas forças - as mesmas plantas, animais, florestas e ventos - que, para os europeus letrados e "civilizados", são apenas cenários, um agradável pano de fundo para nossas preocupações humanas mais urgentes.

A definição mais sofisticada de "mágica" que circula atualmente na contracultura americana é "a habilidade ou poder de alterar nossa consciência por nossa vontade". Nenhuma referência é feita ao motivo pelo qual se altera a consciência. No entanto, nas culturas tribais aquilo que chamamos de "mágica" adquire sentido a partir do fato de que os humanos, num contexto indígena e oral, experimentam sua própria consciência simplesmente como uma forma de percepção mental entre muitas outras. O mágico tradicional cultiva uma habilidade de sair de seu estado comum de consciência justamente para fazer contato com outras formas orgânicas de sensibilidade e atenção com as quais a existência humana está interligada. Somente ao se desvencilhar temporariamente da lógica perceptual aceita por sua cultura, o feiticeiro pode ter esperança de se relacionar com outras espécies em seus próprios termos; somente ao alterar a organização comum de seus sentidos ele será capaz de se relacionar com as múltiplas sensibilidades não humanas que animam a paisagem local. Talvez possamos dizer que é isso que define o xamã: a habilidade de se deslocar para além das fronteiras perceptivas que demarcam sua cultura particular - fronteiras reforçadas pelos costumes sociais, tabus e, sobretudo, o discurso ou linguagem comum - a fim de fazer contato e aprender com os outros poderes da terra. Sua mágica consiste precisamente nessa receptividade ampliada para as solicitações significativas - canções, clamores, gestos - do campo mais amplo, além do humano.

Espaço Ameríndio, Porto Alegre, v. 7, n. 2, p. 64-95, jul./dez. 2013. 
DAVID ABRAM - Um mundo além do humano

A mágica, portanto, talvez em seu sentido mais fundamental, é a experiência de existir em um mundo composto de múltiplas inteligências, a intuição de que cada forma que percebemos - da andorinha mergulhando do alto para pegar uma mosca sobre a grama e até mesmo a própria grama - é uma forma que experiencia, uma entidade com suas próprias predileções e sensações, embora sensações que são muito diferentes das nossas.

Certamente, a função ecológica do xamã, seu papel como intermediário entre a sociedade humana e a terra, não é sempre óbvia à primeira vista, mesmo para um observador sensível. Vemos o feiticeiro sendo chamado para curar um homem da tribo que sofre de insônia ou talvez simplesmente localizar alguns pertences desaparecidos; testemunhamos ele entrar em estado de transe e enviar sua consciência para outras dimensões à procura de compreensão e auxílio. No entanto, não devemos simplesmente interpretar essas dimensões como "sobrenaturais", nem vê-las como esferas inteiramente "internas" à psique pessoal do praticante. Pois é provável que o "mundo interno" de nossa experiência psicológica ocidental, como o paraíso sobrenatural da crença Cristã, tenha origem na perda de nossa reciprocidade ancestral com a terra animada. Quando os poderes animados que nos cercam são subitamente interpretados como sendo menos significativos do que nós, quando a terra geradora é definida abruptamente como um objeto acabado desprovido de suas próprias sensações e sentimentos, então o sentido de uma alteridade selvagem e múltipla (em relação à qual a existência humana sempre se orientou) deve migrar, seja para um paraíso suprassensorial além do mundo natural, seja para dentro do próprio crânio humano - o único refúgio admissível, nesse mundo, para o que é inefável e insondável.

Mas, em culturas genuinamente indígenas e orais, o próprio mundo sensível permanece como a morada dos deuses, dos poderes numinosos que podem tanto sustentar quanto extinguir a vida humana. Não é ao voltar sua consciência para além do mundo natural que o xamã faz contato com os mantenedores da vida e da saúde, nem ao fazer uma jornada para dentro de sua psique pessoal; porém ele faz esse contato impulsionando

Espaço Ameríndio, Porto Alegre, v. 7, n. 2, p. 64-95, jul./dez. 2013. 
DAVID ABRAM - Um mundo além do humano

sua consciência lateralmente, para as profundezas de uma paisagem que é, ao mesmo tempo, sensorial e psicológica, o sonho vivo que compartilhamos com o falcão que desliza pelos ares, a aranha e a pedra em cuja superfície áspera os liquens brotam silenciosamente.

A estreita relação do mágico com a natureza não humana se torna mais evidente quando observamos o contexto facilmente negligenciado de sua prática - não apenas as tarefas mais visíveis de cura e de ritual de auxílio para quais ele é chamado por clientes individuais ou as grandes cerimônias que ele preside e dança, mas também os conteúdos das orações que prepara para tais cerimônias e os incontáveis gestos rituais que realiza quando está sozinho, as propriciações e exaltações diárias que fluem dele em direção à terra e suas várias vozes.

Toda essa atenção à natureza não humana estava, como mencionei, muito longe de meu foco inicial quando embarquei em minha pesquisa sobre os usos da mágica e da medicina na Indonésia, e foi somente de forma gradual que me tornei atento a essa dimensão mais sutil do ofício do mágico nativo. A primeira mudança em minhas ideias preconcebidas veio de forma bastante quieta, quando permaneci por alguns dias na casa de um jovem "balian", ou praticante de mágica, no interior de Bali. Ofereceram-me uma cama simples numa construção separada de uma só peça no complexo da família do balian (em Bali, a maioria das casas compostas são formadas por diversas construções pequenas e separadas, para dormir e para cozinhar, organizadas num terreno único), e, todos os dias de manhã cedo, a esposa do balian vinha para trazer uma pequena, mas deliciosa tigela de frutas, que eu comia sozinho, sentado no chão do lado de fora, encostado contra a parede de minha cabana, assistindo o sol escalar vagarosamente as folhas de palmeira farfalhantes. Quando ela me entregava as frutas, percebi que minha anfitriã carregava uma bandeja que tinha vários pratinhos verdes: na verdade, eles tinham um formato de pequenos barcos, cada um deles era feitos através do entrelaçamento simples e cuidadoso de uma folha de palmeira recém-cortada. Os pratos tinham cinco ou sete centímetros de comprimento e dentro de cada um havia um pequeno punhado de arroz. Depois de entregar meu café da

Espaço Ameríndio, Porto Alegre, v. 7, n. 2, p. 64-95, jul./dez. 2013. 
DAVID ABRAM - Um mundo além do humano

manhã, a mulher e sua bandeja desapareciam de vista atrás de outras construções e, quando ela voltava logo depois para recolher a tigela vazia, a bandeja que ela carregava estava igualmente vazia.

A segunda vez que vi a fileira de pequenos pratos de arroz, perguntei a minha anfitriã para que serviam. Ela me explicou pacientemente que eles eram oferendas para os espíritos da casa. Quando perguntei sobre o termo balinês que ela usou para "espíritos", ela repetiu a mesma explicação, agora em indonésio, que esses eram presentes para os espíritos do complexo de casas da família, e percebi que a havia entendido corretamente. Ela me entregou uma tigela de mamão e manga fatiados e desapareceu pela lateral da casa. Ponderei por um minuto, então coloquei minha tigela no chão, fui até a lateral da cabana e espiei através das árvores. A princípio não pude vê-la, logo, porém, a avistei abaixada ao lado do canto de uma das outras construções arrumando com cuidado o que presumi ser uma das oferendas no chão. Então, ela se levantou com a bandeja, caminhou para outro canto visível da construção e colocou lenta e cuidadosamente outra oferenda no chão. Retornei para minha tigela de frutas e terminei meu café da manhã. Naquela tarde, quando todos estavam ocupados, caminhei até o lugar onde eu a havia visto colocar as duas oferendas. Os pequenos pratos verdes estavam posicionados impecavelmente nos cantos da parte de trás da construção. Mas as porções de arroz que estavam dentro deles haviam desaparecido.

$\mathrm{Na}$ manhã seguinte, terminei de comer as frutas fatiadas, esperei minha anfitriã chegar para pegar a tigela vazia, então fui silenciosamente em direção à parte de trás das construções. Duas oferendas feitas de folhas de palmeira frescas estavam nos mesmos lugares onde as outras estavam no dia anterior. Estas estavam cheias de arroz. No entanto, no momento em que olhei para uma dessas oferendas, percebi, de repente, num sobressalto, que um dos grãos de arroz estava, de fato, se movendo.

Somente quando me ajoelhei para olhar mais de perto percebi uma linha de pequenas formigas pretas serpenteando pela terra até a oferenda. Olhando ainda mais de perto, vi que duas formigas já tinham escalado para dentro da oferenda e estavam empenhadas em pegar o grão de arroz de

Espaço Ameríndio, Porto Alegre, v. 7, n. 2, p. 64-95, jul./dez. 2013. 
DAVID ABRAM - Um mundo além do humano

cima; enquanto assistia, uma delas arrastou o grão para fora da folha, então partiu com o grão de volta ao lado da fila de formigas que se dirigia para a oferenda. A segunda formiga pegou outro grão e desceu com ele, arrastando e empurrando, e caiu da beirada da folha, então uma terceira subiu para dentro da oferenda. A linha de formigas parecia surgir de um tufo denso de grama na base de uma palmeira próxima. Caminhei até a outra oferenda e descobri outra fila de formigas levando embora os grãos brancos. Essa fila surgia do topo de um pequeno monte de terra a cerca de quatro metros das construções. Também havia uma oferenda no chão no canto da minha construção e uma fila quase idêntica de formigas. Entrei em meu quarto rindo comigo mesmo: o balian e sua esposa haviam tido tanto trabalho para acalmar os espíritos da casa com presentes e suas oferendas foram roubadas por pequenos ladrões de seis pernas. Que desperdício! Mas um pensamento estranho me ocorreu: e se as formigas fossem de fato os "espíritos da casa" para quem as oferendas estavam sendo feitas?

Logo comecei a entender a lógica disso. O complexo familiar, como muitos outros dessa ilha tropical, havia sido construído na vizinhança de várias colônias de formigas. Uma vez que se cozinhava muito nesse complexo (que alojava, além do balian, sua esposa e seus filhos, vários membros de sua família) e que também se preparava as oferendas elaboradas em formas de comida para vários rituais e festivais dos vilarejos ao redor, a área e as construções do complexo eram vulneráveis a infestações por parte da enorme população de formigas. Tais invasões poderiam variar de um incômodo raro para cercos ocasionais ou até mesmo periódicos. Ficou claro que as oferendas diárias de folhas de palmeiras serviam para impedir tal ataque por forças naturais que cercavam (e ficavam abaixo) da terra da família. Os presentes diários de arroz mantinham as colônias de formigas ocupadas - e, provavelmente, satisfeitas. Colocadas sempre nos mesmos lugares regulares nos cantos das várias estruturas do complexo, as oferendas pareciam estabelecer certas fronteiras entre as comunidades humanas e de formigas; ao honrar

Espaço Ameríndio, Porto Alegre, v. 7, n. 2, p. 64-95, jul./dez. 2013. 
DAVID ABRAM - Um mundo além do humano

essa fronteira com presentes, os humanos aparentemente esperavam persuadir os insetos a respeitar a fronteira e não entrar nas construções.

No entanto, permaneci intrigado com a asserção de minha anfitriã de que esses eram presentes "para os espíritos". Com certeza, sempre houve uma certa confusão entre nossa noção ocidental de "espírito" (que tão frequentemente é definida em oposição à matéria ou à "carne") e as presenças misteriosas que as culturas tribais e indígenas respeitam tanto. Já fiz referência ao tremendo mal-entendido decorrente do fato de que muitos dos primeiros estudantes ocidentais desses costumes diferentes eram missionários cristãos predispostos a ver fantasmas ocultos e aparições imateriais onde as pessoas tribais estavam simplesmente demonstrando seu respeito aos ventos locais. Enquanto a noção de espírito foi associada pelo Ocidente a uma noção basicamente antropomórfica ou humana, meu encontro com as formigas foi a primeira de muitas experiências que me sugeriu que os "espíritos" de uma cultura indígena são essencialmente aqueles modos de inteligência ou atenção que não possuem uma forma humana.

Como humanos, estamos bem familiarizados com as necessidades e capacidades do corpo humano - vivemos em nossos próprios corpos e então conhecemos, de dentro, as possibilidades da nossa forma. Não podemos conhecer, com a mesma familiaridade e intimidade, como é a experiência de vida de uma cobra verde ou uma tartaruga-mordedora; não podemos experienciar diretamente a exata sensação de um beija-flor saboreando o néctar de uma flor ou de uma seringueira absorvendo a luz do sol. E, no entanto, sabemos como é a sensação de beber de uma fonte fresca de água ou de nos banharmos ao sol. Nossa experiência pode ser, de fato, uma variante desses outros modos de sensibilidade; contudo, não podemos, como humanos, experienciar precisamente as sensações vividas por outras formas. Não sabemos, com clareza absoluta, quais são seus desejos ou motivações, não podemos saber, ou ter certeza de que sabemos, o que eles sabem. É imediatamente evidente para nossos sentidos humanos que o veado experiencia sensações, que ele traz consigo conhecimento de como se orientar na terra, de onde encontrar comida e de

Espaço Ameríndio, Porto Alegre, v. 7, n. 2, p. 64-95, jul./dez. 2013. 
DAVID ABRAM - Um mundo além do humano

como proteger seus filhotes, que ele sabe perfeitamente bem como sobreviver na floresta sem as ferramentas das quais nós dependemos. Também é evidente que a mangueira tem a habilidade de gerar frutos ou que a erva-de-carpinteiro pode baixar a febre de uma criança. Para a humanidade, esses Outros são "portadores" de segredos, providos de uma inteligência que nós frequentemente precisamos: são esses Outros que podem nos informar sobre as mudanças fora de época do tempo ou nos avisar de erupções e terremotos iminentes, que nos mostram, quando estão procurando por alimentos, onde podemos encontrar as frutas silvestres mais maduras ou o melhor caminho de volta para casa. Ao vê-los construírem seus ninhos e abrigos, recolhemos pistas de como fortalecer nossas habitações, e suas mortes nos ensinam sobre as nossas. Recebemos deles incontáveis presentes: comida, combustível, abrigo e vestuário. No entanto, eles ainda são Outros para nós, habitando suas próprias culturas e expondo seus próprios rituais, nunca totalmente compreensíveis.

Além disso, não são somente aquelas entidades reconhecidas pela civilização ocidental como "vivas", não são somente os outros animais e plantas que falam, como espíritos, para os sentidos de uma cultura oral, mas também o rio sinuoso onde os animais bebem e as chuvas torrenciais de monção e a pedra que se encaixa perfeitamente na palma da mão. A montanha, também, tem seus pensamentos. Os pássaros da floresta cantando e conversando enquanto o sol desliza para baixo do horizonte são órgãos vocais da própria chuva tropical5.

É claro que Bali dificilmente pode ser considerada uma cultura aborígene; a complexidade da arquitetura de seus templos e a sofisticação

\footnotetext{
${ }^{5}$ Para as mentes ocidentais, tais visões podem parecer "projeções" temerárias da consciência humana sobre materiais inanimados e mudos, que serviriam, talvez, para a poesia, mas que não têm, de fato, nenhuma relação com as próprias aves e as florestas. Tal é a nossa visão comum. Este texto irá examinar a possibilidade de que é a civilização que sempre foi confusa, e não os povos indígenas. Irá sugerir, e dar evidência, de que só podemos perceber um mundo quando nos projetamos nesse mundo, que só estabelecemos contato com as coisas e os outros quando participamos ativamente deles, lançando nossa imaginação sensorial em direção às coisas, a fim de descobrir como elas transformam e alteram essa imaginação, como nos refletem de volta mudados, como são diferentes de nós. Este texto irá sugerir que a percepção é sempre participatória, e, por isso, essa negação moderna de uma consciência da natureza não humana não nasce de nenhum rigor conceitual ou científico, mas sim de uma inabilidade ou recusa de perceber profundamente outros organismos.
}

Espaço Ameríndio, Porto Alegre, v. 7, n. 2, p. 64-95, jul./dez. 2013. 
DAVID ABRAM - Um mundo além do humano

de seus sistemas de irrigação, o esplendor de seus festivais e artesanatos coloridos evidenciam a influência de várias civilizações, mais notavelmente o complexo hindu da Índia. Contudo, em Bali, essas influências estão completamente entrelaçadas com o animismo indígena do arquipélago indonésio; os deuses e as deusas hindus foram apropriados, por assim dizer, pelos espíritos eruptivos e vulcânicos do terreno local.

No entanto, as culturas animistas subjacentes da Indonésia, da mesma forma que as de muitas ilhas do Pacífico, também estão mergulhadas em crenças frequentemente referidas pelos etnólogos como "culto aos ancestrais", e é possível argumentar que o ritual de reverência feito aos ancestrais dos humanos há muito falecidos (e a hipótese de sua influência na vida presente) facilmente invalida minha hipótese de que os vários "poderes" ou "espíritos" que se movem nos discursos orais dos povos indígenas, estão, afinal de contas, ligados às forças não humanas (mas mesmo assim sensíveis) da paisagem ao redor.

Esta objeção está alicerçada em certos pressupostos implícitos da civilização cristã, tais como o pressuposto de que os "espíritos" de pessoas mortas necessariamente retêm sua forma humana e que eles residem num domínio fora do mundo físico ao qual nossos sentidos nos dão acesso. Contudo, a maioria dos povos tribais indígenas não recorre tão prontamente a um domínio imaterial fora da natureza terrena. Apenas recentemente nossos paraísos estritamente humanos foram abstraídos do mundo sensório que nos rodeia, desse domínio além do humano que é abundante em suas próprias inteligências aladas e poderes de cascos. Para quase todas as culturas orais, a terra sensível que nos envolve é o local de moradia para os vivos e os mortos. O corpo - seja humano ou não - não é ainda um objeto mecânico em tais culturas, mas uma entidade mágica, o aspecto mais sensível da própria mente e a decomposição do corpo na morte, transformando-se em terra, vermes e pó, só pode significar a reintegração gradual dos nossos ancestrais e anciãos à paisagem viva da qual todos nascemos.

Cada cultura indígena elabora esse reconhecimento da metamorfose de seu próprio modo, através da observação do terreno específico onde

Espaço Ameríndio, Porto Alegre, v. 7, n. 2, p. 64-95, jul./dez. 2013. 
DAVID ABRAM - Um mundo além do humano

está situada. Frequentemente a atmosfera invisível que anima o mundo visível - a sutil presença que circula tanto dentro de nós quanto entre todas as coisas - retém o espírito ou o alento da pessoa morta até o momento em que aquele alento entrará e animará outro corpo visível - um pássaro ou um veado ou um campo de grãos selvagens. Algumas culturas costumam queimar, ou "cremar", o corpo a fim de devolver a pessoa mais completamente na forma de fumaça ao ar, enquanto o que parte como chama é oferecido ao sol e às estrelas, e o que permanece em forma de cinza nutre a terra densa. Outras culturas podem desmembrar o corpo, deixando certas partes em locais precisos onde eles serão facilmente encontrados por condores ou onde eles serão consumidos pelos leões da montanha ou por lobos, dessa forma apressando a reencarnação daquela pessoa num domínio animal específico dentro da paisagem. Esses exemplos ilustram de forma simples que a morte, em culturas tribais, inicia a metamorfose em que a presença da pessoa não "desaparece" do mundo sensível (para onde ela iria?), mas, mais do que isso, permanece como uma força animada dentro da vastidão da paisagem, seja sutilmente no vento, ou de modo mais visível, na forma de um animal ou, até mesmo, na manifestação da ira explosiva de um vulcão, sempre a ser apaziguada. Portanto o "culto aos ancestrais" em suas infinitas formas é, em última estância, um outro modo de perceber a natureza não humana; significa não tanto uma admiração ou reverência aos poderes humanos, mas, mais do que isso, uma reverência àquelas formas que a atenção assume quando não está numa forma humana, quando a corporificação humana familiar morre e se decompõe para se tornar parte do cosmos abrangente.

Esse ciclo do humano voltando para o mundo amplo garante que as outras formas de experiência que encontramos - sejam formigas ou salgueiros ou nuvens - nunca são completamente alheias para nós. Apesar das diferenças óbvias em formato, habilidade e jeito de ser, elas permanecem de uma certa forma familiares. Paradoxalmente, é essa

Espaço Ameríndio, Porto Alegre, v. 7, n. 2, p. 64-95, jul./dez. 2013. 
DAVID ABRAM - Um mundo além do humano

percepção de um parentesco ou consanguinidade que torna a diferença, ou alteridade, tão estranhamente potente ${ }^{6}$.

Muitos meses depois de minha chegada a Bali, deixei o vilarejo onde estava para visitar um dos locais não atingidos pela cultura hindu da ilha. Cheguei de bicicleta no começo da tarde, depois da saída do ônibus que levava embora os turistas da praia. Desci alguns degraus que me conduziram a um exuberante vale esmeralda, revestido de penhascos de ambos os lados, inundado com a voz do rio e o suspiro do vento passando pelos pastos altos não colhidos. Numa pequena ponte que cruzava o rio encontrei uma idosa carregando um grande cesto sobre sua cabeça e segurando pela mão uma criança pequena e tímida; a mulher sorriu para mim com um sorriso desdentado e vermelho de uma mascadora de nozde-areca. Parei do outro lado do rio em frente a um enorme complexo coberto de musgo com passagens, salas e pátios esculpidos a mão na pedra vulcânica preta.

Numa curva no cânion abaixo, notei uma nova série de cavernas esculpidas nos penhascos. Essas pareciam mais isoladas e remotas, sem nenhuma trilha visível que conduzisse a elas. Atravessei o pasto para explorá-las. A travessia foi muito mais difícil do que eu esperava, mas depois de me perder nos pastos altos e cruzar o rio três vezes, finalmente me encontrei sob as cavernas. Uma curta escalada no paredão rochoso me levou para a boca de uma delas, onde entrei de quatro. Era uma entrada larga, mas baixa, de talvez apenas um metro de altura, e o interior entrava apenas um metro e meio aproximadamente para dentro da parede do penhasco. O chão e as paredes eram cobertos de musgos, pintando a caverna com padrões verdes e amenizando a dureza da pedra; o lugar, apesar de seu tamanho pequeno - ou talvez por causa dele -, tinha um ar aconchegante. Escalei duas outras cavernas, todas de tamanho

\footnotetext{
${ }^{6}$ A semelhança entre tais visões de mundo animistas e a perspectiva emergente da ecologia contemporânea não é trivial. O geoquímico atmosférico James Lovelock, ao explicar a conhecida hipótese Gaia - uma teoria que enfatiza o papel importante desempenhado pela vida orgânica na modulação incessante das condições atmosféricas e climáticas da terra -, insiste que o ambiente ecológico é, ele próprio, constituído pela vida orgânica e pelos produtos do metabolismo orgânico. Segundo ele, habitamos "um mundo que é o hálito e os ossos dos nossos ancestrais". Veja, por exemplo, "Gaia: the World as Living Organism", em New Scientist, 18 de dezembro de 1986, e Scientists on Gaia, editado por Stephen Schneider e Penelope Boston (Cambridge: M.I.T. Press, 1991).
}

Espaço Ameríndio, Porto Alegre, v. 7, n. 2, p. 64-95, jul./dez. 2013. 
DAVID ABRAM - Um mundo além do humano

aproximado, mas então me senti atraído de volta à primeira, onde me sentei de pernas cruzadas no musgo macio e fiquei olhando para o cânion esmeralda. Estava quieto lá dentro, um tipo de santuário íntimo talhado na pedra. Comecei a explorar a rica ressonância do lugar, primeiro apenas cantarolando, depois entoando um simples cântico que um balian me ensinou alguns dias antes. Estava encantado com os sobretons que a caverna adicionava a minha voz e fiquei lá cantando por um longo tempo. Não percebi a mudança no vento lá fora ou as sombras das nuvens escurecendo o vale, até que a chuva caiu - de repente e com muita força. A primeira tempestade da monção!

Até então, só havia experimentado chuvas fracas na ilha e fiquei assustado com o aguaceiro torrencial que agora fazia com que as pedras rolassem paredão abaixo, formando poças e depois lagoas na paisagem verde, levantando o rio. Estava fora de cogitação voltar para casa - não era possível fazer o caminho de volta até a entrada do vale. Então, agradecido pelo abrigo, descruzei minhas pernas e esperei a tempestade passar. Não demorou muito para que os pequenos filetes de água que desciam pelo paredão se transformassem em córregos e duas pequenas cachoeiras se formassem na boca da caverna. Logo eu estava olhando para uma sólida cortina de água, fina em alguns lugares, onde a imagem do cânion tremulava instável, e descendo espessa em outros. Todos meus sentidos estavam vencidos pela beleza selvagem da cascata e pelo rugido, meu corpo tremia por dentro com a sensação estranha de estar fechado dentro de meu esconderijo.

E então, no meio de todo tumulto, percebi uma atividade pequena e delicada. Bem a minha frente e somente três ou cinco centímetros da torrente em minha direção, uma aranha estava subindo num fio fino esticado de um lado ao outro da boca da caverna. Enquanto assistia, ela ancorou outro fio no topo da abertura, então escorregou de volta através do primeiro fio e juntou os dois no ponto que ficava no meio do caminho entre o teto e o chão. Depois perdi a aranha de vista e por um tempo parecia que ela havia desaparecido, com os fios e tudo, até meu foco a redescobrir. Mais dois fios estavam agora irradiando do centro em direção

Espaço Ameríndio, Porto Alegre, v. 7, n. 2, p. 64-95, jul./dez. 2013. 
ao chão e depois outro; logo a aranha começou a balançar entre eles como numa treliça circular, arrastando sempre um fio crescente que ela afixava a cada alça lançada, enquanto se movia de um para outro, girando em espiral para fora. A aranha parecia totalmente destemida com o tumulto das águas passando por ela, embora de vez em quando ela quebrasse sua dança em espiral e escalasse para o teto ou para o chão para puxar com força os raios para lá, assegurando a tensão dos fios, depois escalasse de volta para onde ela os havia deixado. Sempre que perdia o foco correto, esperava para ver o aracnídeo que girava em espiral e então deixar sua forma de dançar gradualmente desenhar os contornos da rede trazendo-o de volta à visibilidade, prendendo meu foco em cada novo nó de seda enquanto ele se movia, ondulando, meu olhar fixo dentro de um padrão cada vez mais profundo.

E então, abruptamente, meu olhar notou uma estranha incongruência: outro fio se inclinava através da teia, nem irradiando, nem girando em espiral da conjuntura central, violando a simetria. Enquanto eu o seguia com os olhos, ponderando seu propósito no padrão geral, comecei a perceber que o fio estava num plano diferente do resto da teia, pois a teia saía de foco sempre que essa nova linha se tornava mais clara. Logo vi que ela levava a seu próprio centro, cerca de trinta centímetros à direita da primeira, outro centro de forças de onde vários fios se esticavam em direção ao chão e ao teto. E então vi que havia uma aranha diferente tecendo essa teia, testando a sua tensão ao dançar ao seu redor como a primeira fazia, agora posicionando o sedoso fio nas tramas ao redor do ponto nodal e serpenteando para fora. As duas aranhas giravam independentemente uma da outra, mas para meus olhos elas teciam um padrão cruzado simples e único. Essa ampliação de minha visão logo revelou outra aranha girando em espiral na boca da caverna e de repente percebi que haviam muitas teias sobrepostas, irradiando em ritmos diferentes dos inumeráveis centros colocados - algumas mais altas, algumas mais baixas, algumas minuciosamente mais próximas de meus olhos, outras mais afastadas - entre a pedra de cima e a de baixo.

Espaço Ameríndio, Porto Alegre, v. 7, n. 2, p. 64-95, jul./dez. 2013. 
DAVID ABRAM - Um mundo além do humano

Sentei surpreendido e hipnotizado frente a essa extensão cada vez mais complexa de padrões vivos sobre padrões, minha visão mergulhada como uma respiração dentro de um grupo convergente de linhas, então, respirando para fora no espaço aberto, depois mergulhado de volta dentro de outra convergência. A cortina de água tornou-se completamente silenciosa - tentei ouvi-la por um momento, mas não consegui. Meus sentidos estavam em transe.

Tinha a distinta impressão de que eu estava assistindo o nascimento do universo, galáxia sobre galáxia...

A noite preencheu a caverna com escuridão. A chuva não havia cessado. No entanto, de forma estranha, não senti nem frio nem fome somente uma paz notável e um sentimento de estar em casa. Dormi esticando-me sobre o chão úmido e cheio de musgos perto do fundo da caverna.

Quando acordei, o sol estava invadindo o cânion, as vegetações abaixo, ondulando em azuis e verdes brilhantes. Não consegui ver nenhum vestígio das teias, nem de suas tecelãs. Pensando que elas estavam invisíveis a meus olhos sem a cortina de água por trás delas, passei as mãos com cuidado ao redor da abertura da caverna. Mas as teias haviam sumido. Desci de volta para o rio e me lavei, depois caminhei pelo cânion e para fora dele onde minha bicicleta estava secando ao sol e fui em direção ao meu próprio vale.

Depois daquele dia, nunca mais fui capaz de encontrar uma aranha sem sentir uma incrível estranheza e reverência. Com certeza, os insetos e aranhas não são os únicos poderes ou até mesmo presenças centrais, no universo indonésio. Mas eles foram minha apresentação aos espíritos, aos mágicos andantes da terra. Foi com eles que aprendi, pela primeira vez, sobre a inteligência oculta na natureza não humana, a habilidade que uma forma alienígena tem de sensibilizar alguém, de incutir uma reverberação em si mesmo que esmigalha temporariamente as formas habituais de ver e sentir, deixando alguém aberto a todo um mundo vivo, desperto e atento. Foi com esses pequenos seres que meus sentidos aprenderam pela primeira vez sobre os incontáveis mundos dentro dos mundos que giram

Espaço Ameríndio, Porto Alegre, v. 7, n. 2, p. 64-95, jul./dez. 2013. 
DAVID ABRAM - Um mundo além do humano

nos abismos desse mundo que nós habitamos normalmente e foi com eles que aprendi que meu corpo pode, com a prática, entrar de forma sensível dentro dessas dimensões. O ofício preciso e minúsculo das aranhas afiou e focou minha consciência de tal forma que o próprio trabalho de teia do universo, do qual minha própria carne fazia parte, parecia estar sendo tecido por sua arte arcana. Já falei das formigas e dos vaga-lumes, cuja semelhança sensorial com a luz do céu noturno me ensinou a inconstância da gravidade. O transe longo e cíclico a que chamamos de malária também me foi trazido por insetos, neste caso mosquitos, e vivi por três semanas em um estado febril de tremores, suores e alucinações.

Antes eu raramente havia prestado atenção ao mundo natural. Mas meu contato com mágicos e videntes tradicionais estava mudando meus sentidos; tornei-me cada vez mais suscetível às solicitações do não humano. Ao me esforçar para decifrar os gestos estranhos dos mágicos ou ao sondar suas constantes referências aos poderes não vistos e não ouvidos, comecei a ver e ouvir de uma maneira que nunca havia feito antes. Quando um mágico falava de um poder ou uma "presença" no canto de sua casa, aprendi a perceber o raio de sol que estava entrando naquele momento por uma fenda no teto, iluminando uma coluna de poeira suspensa, e a conceber que aquela coluna de luz era de fato um poder, influenciando as correntes de ar com seu calor e, de fato, influenciando toda a atmosfera do quarto; apesar de eu não tê-la visto conscientemente antes, ela já estava estruturando minha experiência. Meus ouvidos passaram a responder, de uma nova maneira, às canções dos pássaros não mais apenas uma melodia de fundo para a fala humana, mas falas significativas por si mesmo, respondendo e comentando eventos do mundo vivo a sua volta. Passei a ser um aprendiz das diferenças sutis: a maneira como a brisa pode agitar uma única folha de uma árvore, deixando as outras folhas quietas e imóveis (não teria sido aquela folha, então, tocada por uma mágica?); ou a maneira como a intensidade do calor do sol se expressa no ritmo preciso dos grilos. Andando por trilhas, aprendi a diminuir meu passo para poder sentir as diferenças entre duas colinas próximas, ou experienciar a presença de um campo particular num

Espaço Ameríndio, Porto Alegre, v. 7, n. 2, p. 64-95, jul./dez. 2013. 
DAVID ABRAM - Um mundo além do humano

certo momento do dia, em que, como me foi dito por um dukun local, o local tinha um poder especial e ofertava dons únicos. Era um poder comunicado aos meus sentidos pela forma como as sombras das árvores se apresentavam naquela hora, pelos cheiros que permaneciam na superfície das gramas sem serem soprados para longe pelo vento, e outros elementos que eu só podia identificar depois de parar e escutar por muitos dias.

E, gradualmente, então, outros animais começaram a cruzar meus caminhos, como se a qualidade da minha postura ou o ritmo da minha respiração tivesse desarmado suas defesas; de repente, encontrava-me cara a cara com macacos e grandes lagartos que não deslizavam para longe quando eu falava, mas se inclinavam em minha direção com uma certa curiosidade. Na parte rural de Java, frequentemente percebia que os macacos me acompanhavam pelos galhos mais altos e os corvos caminhavam em minha direção grasnando pela rua. Quando eu estava em Pangandaran, uma reserva natural numa península na costa sul de Java ("um lugar de muitos espíritos", disse-me um pescador local), saí de um bosque e quando percebi estava face a face com um lindo e raro bisão que existe apenas nessa ilha. Nossos olhos se fixaram uns nos outros. Quando ele bufou, eu bufei de volta; quando ele trocou de apoio, também mudei minha postura; quando balancei minha cabeça, ele balançou a sua em resposta. Vi-me no meio de uma conversa não verbal com esse Outro, um dueto gestual em que minha percepção consciente tinha um papel pequeno. Foi como se meu corpo com sua ação fosse de repente motivado por uma sabedoria mais antiga que minha mente pensante, como se fosse guiado e movido por um logos mais profundo que as palavras, ditado pelo corpo do Outro, pelas árvores e pelas rochas sob nossos pés.

A falta de aptidão da Antropologia para perceber a aliança dos xamãs com a natureza não humana leva a circunstâncias curiosas no "mundo desenvolvido" de hoje, onde muitas pessoas, em busca de entendimento espiritual, estão se inscrevendo em workshops relacionados a métodos "xamânicos" de descoberta e revelação pessoais. Alguns psicoterapeutas e médicos se especializaram em "técnicas de cura

Espaço Ameríndio, Porto Alegre, v. 7, n. 2, p. 64-95, jul./dez. 2013. 
DAVID ABRAM - Um mundo além do humano

xamânicas". O "xamanismo" passou, assim, a implicar uma forma de terapia alternativa; a ênfase desses novos profissionais do xamanismo popular é no insight pessoal e na cura. Esses são, com certeza, objetivos nobres, mas, ao mesmo tempo, são secundários e derivativos do papel primário do xamã indígena, um papel que não pode ser preenchido sem uma exposição longa e continuada à natureza não domesticada, a seus padrões e vicissitudes. Imitar os métodos curativos dos xamãs indígenas, sem seu conhecimento íntimo da ampla comunidade da natureza, não pode, se estou correto, fazer mais do que simplesmente trocar certos sintomas por outros ou mudar o locus do desconforto de um lugar para outro dentro da comunidade humana. Pois a fonte do stress se origina na relação entre a comunidade humana e a paisagem natural.

Obviamente, a sociedade industrial ocidental, com sua escala massiva e economia amplamente centralizada, dificilmente pode ser vista em relação a alguma paisagem ou ecossistema específico; a ecologia além do humano com a qual ela está diretamente envolvida é a própria biosfera. Infelizmente, nossa relação cultural com a biosfera terrestre não pode, de maneira alguma, ser considerada recíproca ou equilibrada: com milhares de aves de florestas não regenerativas desaparecendo a cada hora e centenas de espécies que nos acompanham se tornando extintas a cada mês como resultado dos excessos de nossa civilização, não podemos nos surpreender com a quantidade de doenças epidêmicas em nossa cultura, desde doenças imunológicas e cânceres cada vez mais graves, passando por angústias psicológicas, depressões e suicídios cada vez mais frequentes, tão comuns no nosso dia a dia, chegando ao número cada vez maior de assassinatos domésticos e em massa cometidos sem motivo nenhum por indivíduos considerados coerentes.

De uma perspectiva animista, a origem mais óbvia de toda essa aflição, tanto física quanto psicológica, reside na violência acima citada, perpetrada sem necessidade, contra a ecologia do planeta, por nossa civilização; só seremos capazes de curar o planeta ao diminuir a violência. Mesmo que, inicialmente, essa afirmação possa soar como uma simples declaração de fé, ela passa a ter um sentido eminente e óbvio no momento

Espaço Ameríndio, Porto Alegre, v. 7, n. 2, p. 64-95, jul./dez. 2013. 
DAVID ABRAM - Um mundo além do humano

em que reconhecemos nossa dependência completa dos inúmeros outros organismos com os quais evoluímos. Presos por uma grande quantidade de abstrações, com nossa atenção hipnotizada por uma série de tecnologias artificiais que apenas nos refletem de volta a nós mesmos, torna-se muito fácil para nós esquecermos nossa inerência carnal numa matriz de sensações e sensibilidades além do humano. Nossos corpos se formaram numa reciprocidade delicada com as múltiplas texturas, sons e formas de uma terra animada - nossos olhos evoluíram em interações sutis com outros olhos, assim como nossos ouvidos estão sintonizados, por sua própria estrutura, ao uivo dos lobos e ao grasno dos gansos. Isolar-nos dessas outras vozes, continuar a condenar, através de nosso estilo de vida, essas outras sensibilidades ao esquecimento da extinção, significa roubar nossos sentidos de sua integridade e roubar a coerência de nossas mentes. Apenas somos humanos quando estamos em contato, e convívio, com o que não é humano.

Apesar das ilhas da Indonésia abrigarem uma variedade surpreendente de aves, minha iniciação no mundo das aves só ocorreu verdadeiramente quando fui estudar com o povo Xerpa dos altos do Himalaia. O Himalaia é um conjunto de montanhas jovens, cujos picos ainda não estão arredondados pela ação incessante do vento e do gelo, e, por isso, a dimensão fundamental de sua paisagem visível é espantosamente vertical. Mesmo nos picos mais altos, é raro ter uma visão do horizonte distante; pelo contrário, a visão da pessoa é direcionada para cima pela face íngreme da montanha seguinte. Toda a terra subiu em direção ao céu de uma maneira ainda evidente pelas linhas e sulcos das paredes das montanhas, e esse dinamismo antigo se comunica imediatamente com o corpo sensorial.

Num mundo como esse, os que habitam e voam no céu são os poderes primordiais. Eles são os únicos que se movem facilmente nessa zona, mergulhando em direção ao chão para se tornarem uma partícula perto do fundo do vale ou girando em direção às alturas em correntes invisíveis. Somente os seres alados possuem o conhecimento instantâneo do que está acontecendo no lado longínquo do pico seguinte, e, por isso,

Espaço Ameríndio, Porto Alegre, v. 7, n. 2, p. 64-95, jul./dez. 2013. 
DAVID ABRAM - Um mundo além do humano

apenas observando-os podemos nos manter informados sobre as mudanças climáticas iminentes, assim como mudanças sutis de fluxo e densidade das correntes de ar no próprio vale. Muitos dos xamãs que conheci no Nepal consideravam os pássaros como familiares próximos. Os corvos estão constantemente comentando sobre a vida do vilarejo. Os pássaros menores, em bando, fazem acrobacias uniformes sobre os telhados do vilarejo, girando e mudando de direção em um movimento perfeitamente coordenado, o bando todo parecendo-se com uma bandeira que flutua e tremula com as correntes de ar que passam pelo vilarejo e, então, desce em conjunto para, em seguida, ser carregado para cima pelo vento, ondulando e ampliando o desenho.

Fiquei por um tempo hospedado com um dzankri xerpa, cuja casa de pedras foi escavada numa das laterais íngremes de uma montanha da região de Khumbu no Nepal. Numa de nossas caminhadas pelas trilhas estreitas que circundavam a montanha, o dzankri me mostrou uma rocha específica se projetando num despenhadeiro onde ele já havia "dançado" na tentativa de realizar curas particularmente difíceis. Reconheci a rocha alguns dias depois, quando estava voltando dos pastos dos iaques que ficam numa parte mais alta que a casa do dzankri, e subi na rocha, não para dançar, mas para observar os líquens vermelhos e brancos que davam vida a sua superfície e também para descansar. Do outro lado do vale, dois abutres-barbudos flutuavam entre picos reluzentes e cobertos de neve. Era um dia de um azul vibrante no Himalaia, transparente como um cálice. Depois de algum tempo, tirei uma moeda de prata de meu bolso e comecei um exercício simples de prestidigitação com as mãos, rolando a moeda entre meus dedos da mão direita. Comecei a praticar essa atividade, monótona por um lado, em resposta ao incessante movimento das contas de oração dos Xerpa mais velhos, uma prática normalmente acompanhada pela repetição de um mantra: "Om Mani Padme Hum" (Om a Joia no Lotus). Mas não havia nenhum mantra para acompanhar o giro da minha moeda, além da minha respiração silenciosa e da luz deslumbrante do sol. Percebi que um dos condores se afastou de seu parceiro e estava agora voando sobre o vale, com suas asas bem abertas. Enquanto via ele ficar maior,

Espaço Ameríndio, Porto Alegre, v. 7, n. 2, p. 64-95, jul./dez. 2013. 
DAVID ABRAM - Um mundo além do humano

percebi extasiado que ele estava vindo em minha direção; parei de girar a moeda e o encarei. Justamente então o lammergeier parou em seu voo, imóvel por um instante contra o pico, então, mudou de direção e voou para junto de seu parceiro no horizonte. Desapontado, peguei a moeda e comecei a girá-la entre meus dedos novamente, sua superfície prateada pegando os raios do sol enquanto girava e os refletindo de volta para o céu. Instantaneamente, o condor saiu de seu caminho e começou a planar de volta fazendo um grande arco. Mais uma vez, assisti seu tamanho aumentar. À medida que o tamanho espetacular do pássaro se tornou aparente, senti minha pele arrepiar e ficar viva, como um enxame de abelhas em movimento, e um zumbido tomou conta de meus ouvidos. A moeda continuava girando entre meus dedos. A criatura ficava cada vez maior e maior, até que, de repente, estava lá - uma silhueta imensa pairando sobre minha cabeça, as penas enormes da asa sussurrando levemente enquanto dominavam a brisa. Meus dedos estavam congelados, incapazes de se mexer; a moeda caiu da minha mão. E, então, me senti desnudado por um olhar infinitamente mais lúcido e preciso que o meu. Não sei quanto tempo fiquei paralisado, só sei que sentia o ar passando pelos meus joelhos nus e ouvia o vento sussurrando entre minhas penas por muito tempo depois do Visitante ter partido.

Voltei aos Estados Unidos, cuja única espécie indígena de condor estava à beira da extinção, principalmente devido ao envenenamento por chumbo oriundo de balas presentes na carniça que o pássaro consome. Mas não pensei nisso. Estava empolgado com as novas sensibilidades que foram atiçadas em mim - com minha consciência recentemente descoberta de um mundo além do humano, do imenso potencial da terra e, especialmente, da inteligência aguçada dos outros animais, grandes e pequenos, cujas vidas e culturas se entrecruzam com as nossas. Choquei vizinhos ao conversar com esquilos, que rapidamente desciam dos troncos de suas árvores e atravessavam o gramado para brincar comigo, ou olhando por horas a fio uma garça pescando em um estuário das proximidades ou as gaivotas derrubando mariscos do alto sobre rochas na praia para abri-los.

Espaço Ameríndio, Porto Alegre, v. 7, n. 2, p. 64-95, jul./dez. 2013. 
DAVID ABRAM - Um mundo além do humano

Todavia, aos poucos, fui perdendo minha clareza da consciência própria dos animais. A técnica das gaivotas de abrir mariscos começou a parecer um comportamento praticamente automático, e eu não conseguia perceber facilmente a atenção que elas precisam dar a cada nova concha. Talvez cada concha fosse exatamente igual à última, e nenhuma atenção voluntária fosse, de fato, necessária...

Peguei-me, então, observando a garça-real de uma perspectiva externa a seu mundo, observando, com interesse, seu caminhar cuidadoso de passos altos e o mergulho repentino do seu bico na água, mas não mais sentindo com meus próprios músculos seu estado de alerta tenso e, ao mesmo tempo, equilibrado. Com estranheza, percebi que os esquilos do subúrbio não respondiam mais a meus chamados na tentativa de imitar sua língua. Por mais que quisesse, não conseguia mais focar minha atenção para participar de seu mundo como eu fizera com tanta facilidade há algumas semanas, pois minha atenção era rapidamente desviada por minhas deliberações verbais internas de um tipo ou de outro - por uma conversa que parecia acontecer inteiramente em minha cabeça. Os esquilos não tinham nenhum papel nessa conversa.

Foi se tornando cada vez mais claro, a partir de livros e artigos e discussões com várias pessoas, que os outros animais não eram tão acordados e conscientes como eu havia presumido, que eles não possuíam nenhuma linguagem e, por isso, nenhuma possibilidade de pensamento, e que, mesmo suas respostas aparentemente espontâneas ao mundo a seu redor, eram comportamentos amplamente "programados", "codificados" no material genético que está sendo, agora, mapeado pelos biólogos. O fato é que, quanto mais eu falava sobre os animais, menos possível era falar com eles. Paulatinamente comecei a perceber que não há uma base comum entre o intelecto humano ilimitado e as sensações limitadas dos outros animais, nenhum meio através do qual nós e eles pudéssemos nos comunicar e estabelecer relações de reciprocidade.

À medida que a paisagem expressiva e senciente foi, aos poucos, enfraquecendo ao se deparar com minhas preocupações mais exclusivamente humanas, ameaçando se tornar pouco mais que uma ilusão

Espaço Ameríndio, Porto Alegre, v. 7, n. 2, p. 64-95, jul./dez. 2013. 
DAVID ABRAM - Um mundo além do humano

ou fantasia, comecei a sentir - principalmente em meu peito e abdômen como se estivesse sendo privado de fontes vitais de nutrição. Estava, de fato, me reaclimatando a minha própria cultura, tornando-me mais sintonizado com seus estilos de discurso e interação, ainda que meus sentidos corporais parecessem estar perdendo sua acuidade, tornando-se menos atentos a mudanças e padrões sutis. O tritinar dos grilos e, até mesmo, o canto dos melro-pretos locais, facilmente desapareciam de minha percepção depois de alguns instantes, e era apenas com muito esforço que eu conseguia trazê-los de volta ao campo perceptivo. O voo dos pardais e das libélulas não mais me prendiam por muito tempo, se é que chamavam minha atenção. Minha pele parou de registrar as várias mudanças da brisa, e os cheiros pareciam ter desaparecido quase completamente do mundo, meu nariz só acordando uma ou duas vezes ao dia, talvez enquanto eu cozinhava ou levava o lixo para fora.

No Nepal, o ar estava sempre tomado por odores - seja nas cidades, onde o aroma dos incensos se misturava com os cheiros de carnes assando, doces de mel e frutas à venda na feira e com o cheiro fétido do lixo orgânico apodrecendo nos barrancos e, às vezes, com o de corpos sendo cremados perto do rio; ou nos altos das montanhas, onde o vento levava o aroma das incontáveis flores selvagens e da terra recém-revirada ao redor dos vilarejos, onde o esterco cheiroso dos iaques ficava secando em formato de massas redondas perto das paredes externas das casas, para ser usado, quando seco, como combustível dos fogos caseiros, e onde a fumaça desses tantos fogos caseiros se mesclavam ao ar da rua. E sons também: os cantos dos adeptos e monges aspirantes se misturavam com o bater dos sinos das preces de ladeiras próximas ou distantes, acompanhados do grasnido estridente dos corvos, o suspiro do vento passando pelos caminhos que cortam as montanhas, o farfalhar das bandeiras de reza e o murmúrio distante do rio caindo em cascata no desfiladeiro longínquo.

Lá, o ar era uma presença espessa e ricamente texturizada, preenchido por influências invisíveis mas, ainda assim, palpáveis, olfatórias e audíveis. Porém, nos Estados Unidos, o ar parecia fino e privado de

Espaço Ameríndio, Porto Alegre, v. 7, n. 2, p. 64-95, jul./dez. 2013. 
DAVID ABRAM - Um mundo além do humano

substâncias ou influências. Aqui, o ar não era um meio sensível - o sentido matriz de nosso hálito e do hálito de outros animais, plantas e solos -, mas simplesmente uma ausência, a referência que se fazia a ele, de fato, nos discursos do dia a dia, era a um mero espaço vazio. Consequentemente, nos Estados Unidos, me peguei parando perto de fogueiras feitas com madeira e, até mesmo, de depósitos de lixo assustando meus amigos - , porque apenas uma tal intensidade de cheiros conseguia lembrar meu corpo de sua imersão num meio envolvente, e, com essa experiência de estar imerso num mundo de influências, veio uma série de memórias corporais de meu ano entre os xamãs e as pessoas dos vilarejos rurais da Ásia.

Comecei a encontrar outras formas, também, de buscar as sensações e percepções bastante diferentes com a que havia me acostumado no "mundo subdesenvolvido", indo viver por períodos extensos em reservas indígenas no deserto do sudoeste e na costa noroeste, ou fazendo trilhas por semanas seguidas em áreas isoladas dos Estados Unidos. Aos poucos, comecei a me perguntar se as suposições de minha cultura em relação à ausência de consciência dos outros animais e da própria terra não seriam menos o resultado de um raciocínio cuidadoso e criterioso do que uma inabilidade estranha de perceber com clareza os outros animais - uma verdadeira inabilidade de ver claramente, de se focar em qualquer coisa além do domínio humano da tecnologia ou de ouvir qualquer outra coisa significante além do discurso humano. Os tristes resultados de nossas interações com o restante da natureza eram anunciados em todos os jornais - do esgotamento da camada superficial do solo devido a técnicas agrícolas industriais à contaminação das águas subterrâneas por resíduos industriais, da rápida destruição das florestas antigas à, pior do que qualquer outra coisa, extinção cada vez mais acelerada das espécies que nos acompanham -, e essas ocorrências marcantes e perturbadoras, todas conduzindo imediatamente às atividades atuais da humanidade "civilizada", de fato, sugeriam a possibilidade de que havia um problema de percepção em minha cultura, que a humanidade moderna e "civilizada" simplesmente

Espaço Ameríndio, Porto Alegre, v. 7, n. 2, p. 64-95, jul./dez. 2013. 
DAVID ABRAM - Um mundo além do humano

não percebia a natureza ao seu redor de forma clara, se é que a percebia em algum momento.

As experiências que mudaram o foco da minha pesquisa na Indonésia e no Nepal rurais me mostraram que a natureza não humana pode ser percebida e experenciada com muito mais intensidade e nuances do que geralmente se reconhece no Ocidente. $O$ que gerou aquela sensibilidade ampliada para a realidade supra-humana, a profunda atenção direcionada às outras espécies e à Terra, que é evidenciada em muitas dessas culturas e que tanto alterou minha consciência de forma que meus sentidos agora se sentem embrutecidos e famintos por causa dos padrões de minha própria cultura? Ou, invertendo a pergunta, o que gerou a ausência dessa atenção no Ocidente moderno? Afinal, a cultura ocidental também tem suas origens indígenas. Se a sintonia relativa com a natureza circundante encontrada em culturas indígenas está ligada a um modo mais primordial e participativo de percepção, então como essa reciprocidade sensorial veio a estar tão ausente na civilização ocidental? Ou seja, como nos tornamos tão surdos e tão cegos para a existência vital de outras espécies e para as paisagens animadas que eles habitam que agora tão casualmente levamos à destruição?

Com certeza, nossa falta de atenção para com a natureza não humana é atualmente sustentada por formas de falar que simplesmente negam a inteligência de outras espécies e da natureza em geral, bem como pelas próprias estruturas de nossa existência civilizada - pelo zumbido incessante de motores que barram as vozes dos pássaros e dos ventos; por luzes elétricas que eclipsam não só as estrelas, mas a própria noite; por ar-"condicionados" que escondem as estações do ano; por escritórios, automóveis e shoppings que, por fim, tornam qualquer necessidade de dar um passo fora do mundo puramente humano completamente supérflua. Conscientemente encontramos a natureza não humana apenas da forma como tem sido limitada pela nossa civilização e suas tecnologias: através de nossos animais domesticados, na televisão, ou no zoológico (ou, na melhor das hipóteses, em "reservas naturais" cuidadosamente gerenciadas). As plantas e os animais que consumimos não são nem

Espaço Ameríndio, Porto Alegre, v. 7, n. 2, p. 64-95, jul./dez. 2013. 
DAVID ABRAM - Um mundo além do humano

coletados, nem caçados, são criados, e colhidos em enormes fazendas mecanizadas. A "natureza", ao que parece, tornou-se simplesmente um estoque de "recursos" para a civilização humana, e, por isso, não podemos ficar surpresos que nossos olhos e ouvidos civilizados estejam, de certa forma, alheios à existência de perspectivas que não são, de nenhum modo, humanas ou que uma pessoa indo ou voltando para o Ocidente vindo de uma cultura não industrial ficaria perplexa e confusa com a ausência perceptível de poderes não humanos.

Ainda assim, a mercantilização atual da "natureza" pela civilização nos diz pouco ou nada a respeito da mudança de percepção que possibilitou essa redução do animal (e da terra) a um objeto, pouco sobre o processo pelo qual nossos sentidos abandonaram, pela primeira vez, o poder do Outro, a visão que por tanto tempo havia motivado nossos rituais mais sagrados, nossas danças e nossas orações.

Mas podemos ter alguma esperança de ter um vislumbre desse processo, que deu origem a muitos dos hábitos e preconceitos linguísticos que agora estruturam nossa própria maneira de pensar? Certamente não, se olharmos para essa origem de dentro da própria civilização que a engendrou. Mas talvez possamos tomar uma posição na aresta dessa civilização, como um mágico, ou como uma pessoa que, tendo vivido entre outra tribo, não pode mais voltar totalmente para sua própria. Ela permanece metade dentro e metade fora de sua comunidade, aberta, também, às mudanças de vozes e às formas oscilantes que rastejam e pairam além das paredes espelhadas da cidade. E mesmo lá, movendo-se ao longo dessas paredes, ela pode esperar encontrar as pistas precisas para o mistério de como tais paredes foram erguidas e de como uma fronteira simples tornou-se uma barreira, mas só se o momento for oportuno - isto é, só se a margem que ela frequenta for uma aresta temporal, bem como espacial, e a estrutura temporal que a circunda estiver prestes a se dissolver ou se metamorfosear em outra coisa.

Espaço Ameríndio, Porto Alegre, v. 7, n. 2, p. 64-95, jul./dez. 2013. 